\title{
Crystallization of Authigenic Carbonates in Mud Volcanoes at Lake Baikal
}

\author{
A. A. Krylov ${ }^{a}$, O. M. Khlystov ${ }^{b}$, T. I. Zemskaya ${ }^{b}$, H. Minami ${ }^{a}$, A. Hachikubo ${ }^{a}$, H. Shoji ${ }^{a}$, M. Kida $^{c}$, \\ T. P. Pogodaeva ${ }^{b}$, L. Naudts ${ }^{d}$, and J. Poort ${ }^{d}$ \\ ${ }^{a}$ Kitami Institute of Technology, Kitami, Japan \\ e-mail:akrylov@gmail.ru \\ ${ }^{b}$ Institute of Limnology, Siberian Branch, Russian Academy of Sciences, Irkutsk, Russia \\ ${ }^{c}$ National Institute of Advanced Industrial Science and Technology, Sapporo, Japan \\ ${ }^{d}$ Renard Center of Marine Geology, Ghent University, Ghent, Belgium
}

Received October 14, 2007

\begin{abstract}
This paper presents data on authigenic siderite first found in surface sediments from mud volcanoes in the Central (K-2) and Southern (Malen'kii) basins of Lake Baikal. Ca is the predominant cation, which substitutes $\mathrm{Fe}$ in the crystalline lattice of siderite. The enrichment of the carbonates in the ${ }^{13} \mathrm{C}$ isotope (from +3.3 to $+6.8 \%$ o for the Malen'kii volcano and from +17.7 to $+21.9 \%$ o for $\mathrm{K}-2$ ) results from the crystallization of the carbonates during methane generation via the bacterial destruction of organic matter (acetate). The overall depletion of the carbonates in ${ }^{18} \mathrm{O}$ is mainly inherited from the isotopic composition of Baikal water.
\end{abstract}

DOI: $10.1134 / \mathrm{S} 0016702908100030$

\section{INTRODUCTION}

Lake Baikal is the world's largest natural reservoir of fresh water. It is located in Central Asia and was formed by continental rifting. The lake is up to $1642 \mathrm{~m}$ deep, lies in the central part of a tectonically active zone, and contains a $7.5-\mathrm{km}$ sequence of sediments (the oldest of which were provisionally dated at the Oligocene [1]). Morphologically, the lake is subdivided into three deep basins (Southern, Central, and Northern) separated by submarine highs: the BuguldaSelenga Wall and the Akademicheskii Ridge (Fig. 1).

The occurrence of gas hydrates $(\mathrm{GH})$ is a unique feature of Baikal; it is the only freshwater reservoir in which gas hydrates were discovered. The possibility of GH occurrence in Baikal sediments was suggested as early as 1980 [2]; later, a BSR seismic reflector was discovered in the course of multichannel seismic survey [3]. The first GH samples were lifted in 1997 from depths of 121 and $161 \mathrm{~m}$ with the core of Hole BDP-97, which was drilled in the Southern Basin of Baikal [4].

Acoustic and sonar measurements conducted in the Southern Basin in 1999 resulted in the discovery of a number of equant structures characterized by the distortion of the acoustic signal $[5,6]$. The sonar imagery provided no evidence of the ejection of mud material, and the craters were poorly pronounced. Because of this, the structures (which were then named Bol'shoi, Malen'kii, Malyutka, and Staryi) were classed as seeps [6]. In March of 2000, the first bottom methane hydrates were separated from the surface sediments of seep Malen'kii [6-9]. The occurrence of Pliocene dia- toms in Holocene sediments from this structure suggests that they were brought to the surface together with methane fluid from depths of $>300 \mathrm{~m}$ [8]. Later, fragments of poorly rounded solid platy rocks and lumps of dense Pleistocene clay were lifted from the same area, and this suggested the presence of mud-volcano breccia and provided grounds to class seep Malen'kii as a mud volcano [10]. Later expeditions detected GH in structures K-2 (Kukui Canyon in the Central Basin) and Bol'shoi (Southern Basin), which also are (judging from the presence of mud-volcano breccia) mud volcanoes [11].

GH accumulations at submarine fluid discharge sites are usually marked by authigenic carbonates. The genesis of the latter is usually explained by the anaerobic bacterial oxidation of methane [12-14 and others]. It has long been thought that the bottom sediments of Baikal are practically carbonate-free [15] because of the low alkalinity of the water (which contains $66 \mathrm{mg} / \mathrm{lHCO}_{3}^{-}$on average [16]) and the one to two orders of magnitude undersaturation of the pore solutions in $\mathrm{Ca}[17,18]$. Nevertheless, the occurrence of minor Mn amounts in the sediments is thought to facilitate the crystallization of rhodochrosite [18]. Minute granules of this mineral were found in the vicinity of a thermal seep in Frolikha Bay at the northern tip of the lake [17]. Carbonates of siderite and rhodochrosite composition were also found in the core of Hole BDP-98 drilled at the Akademicheskii Ridge. The minerals occurred in the depth interval of 100-600 $\mathrm{m}$ in the form of minor nodules $(<1 \mathrm{~mm}$ in diameter $)$ or the 


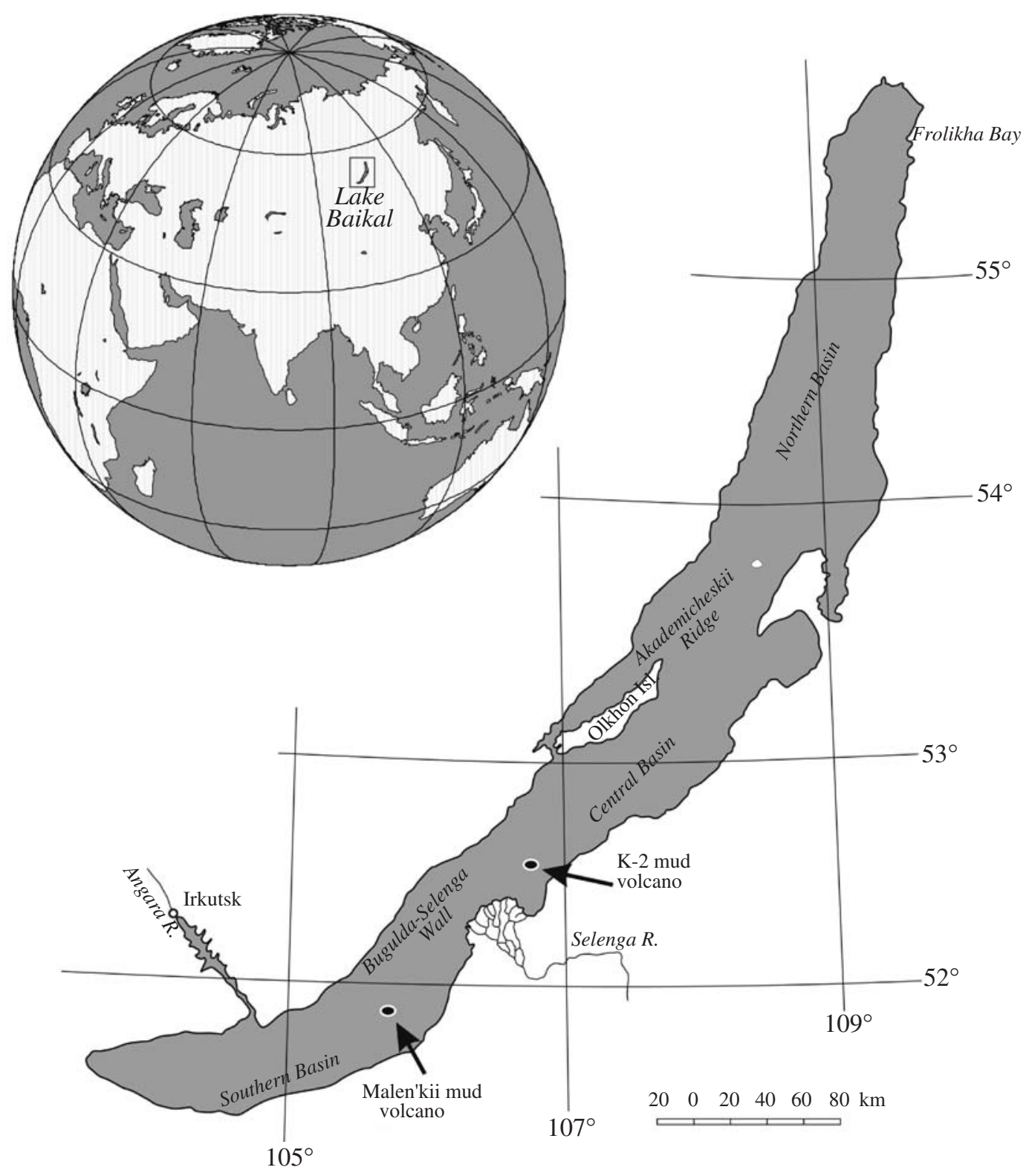

Fig. 1. Location map of the mud volcanoes.

cement of the sediments [19]. The isotopic composition of siderite from a depth of $600 \mathrm{~m}$ indicates that the mineral was formed as a consequence of methane generation [20].

This paper reports the first data on authigenic carbonate found at gas hydrate-bearing mud volcanoes of Lake Baikal and presents a model for their genesis.

\section{MATERIALS AND METHODS}

Our carbonate samples were taken from two gas hydrate-bearing mud volcanoes (Fig. 1): Malen'kii in the Southern Basin (ice expedition and cruises of the R/V G.Yu. Vereshchagin in 2000 and 2003-2005) and
K-2 (Kukui Canyon, Central Basin, cruise of the R/V G.Yu. Vereshchagin in 2005). The samples were collected with a bottom grab (sites 2003G2 and 2000D at Malen'kii), a 1.5-m benthos tube (Site 2003BGC7, Malen'kii), and a 5-m gravity corer (sites 2005St2GC1 at K-2; 2005St3GC1 and 2004StGC3 at Malen'kii). The analytical operations were conducted at laboratories of the Kitami Institute of Technology, Kitami, Japan, and the Institute of Limnology, Siberian Division, Russian Academy of Sciences, Irkutsk, Russia.

Pore waters were expelled from the samples by a specialized press aboard the vessel, and the samples were analyzed for $\mathrm{Mn}$ and $\mathrm{Fe}$ by atomic absorption on a Hitachi Z-2700 spectrometer. The concentrations of 
sulfates and bicarbonates were measured by liquid chromatography on a Milichrom-2A chromatograph.

Hydrate gas samples were collected by spontaneous degassing through saturated salt solution. Gas was extracted from the sediments by the head space technique. The molecular composition of the samples thus obtained was analyzed on a SHIMADZU GC-14B chromatograph (equipped with FID and TCD detectors).

The X-ray diffraction crystal analysis of the carbonates was conducted on a Rigaku RINT 1200 diffractometer with $\mathrm{Cu}$ radiation at $2 \Theta$ of $20-50^{\circ}\left(3-60^{\circ}\right.$ for a few selected samples), counting time at $2 \mathrm{~s}$, with a step of $0.01^{\circ}$; the standard was quartz.

$\mathrm{Ca}, \mathrm{Mg}, \mathrm{Fe}$, and $\mathrm{Mn}$ concentrations in carbonates were determined by ICP-AES on a Hitachi 306 . The concentrations of these elements were also measured at spots in siderite crystals on a JEOL scanning electron microscope equipped with an EDS analytical system (JEOL, JSM-7400F, EDS EX-23000BU).

The $\delta^{13} \mathrm{C}$ and $\delta^{18} \mathrm{O}$ values of carbonates and the $\delta^{13} \mathrm{C}$ and $\delta \mathrm{D}$ of the hydrate gas and gas from sediments were analyzed on a Finnigan Delta plus XP mass spectrometer. Carbonate samples (1-3 mg) were completely dissolved in $100 \%$ phosphoric acid for $14 \mathrm{~h}$ at a temperature of $70^{\circ} \mathrm{C} . \mathrm{CO}_{2}$ released during the first five minutes was removed to preclude contamination with the possible presence of minor amounts of calcite, and $\mathrm{CO}_{2}$ for the measurements was automatically brought to the mass spectrometer with a Gas-Bench device. The standard was NBS-19 certified limestone standard. The results were brought to the VPDB scale. The obtained $\delta^{18} \mathrm{O}$ values were corrected for $-1 \%$ in order to account for fractionation between siderite and phosphoric acid at $70^{\circ} \mathrm{C}[21,22]$. However, the actual fractionation value was somewhat smaller due to the substitution of $\mathrm{Fe}^{2+}$ for $\mathrm{Ca}$ and $\mathrm{Mn}$.

\section{RESULTS}

\section{Lithology of the Bottom Sediments}

Central Basin (K-2). Carbonates from K-2 mud volcano were collected from the $135-\mathrm{cm}-$ long core 2005St2GC1 (Fig. 2). The sediments were gas-rich dark gray silt-pelite with diatoms. Soft carbonate nodules occur at depth intervals of 34-35 and 60-63 cm. These nodules are slightly denser and paler than the surrounding sediment and are approximately $1 \mathrm{~cm}$ across. Two GH intervals occur at depths of 97-105 and 115-135 cm. The upper one contains aggregates of granules 1-7 $\mathrm{mm}$ in diameter, and the lower one contains massive $\mathrm{GH}$ with occasional inclusions of large granules.

Southern Basin (Malen'kii) Carbonates in deposits of the Malen'kii mud volcano morphologically differ from those described above. These are solid semirounded platy aggregates from 1 to $5 \mathrm{~cm}$ across and approximately $0.5 \mathrm{~cm}$ thick.

\footnotetext{
GEOCHEMISTRY INTERNATIONAL Vol. 46 No. 10



Fig. 2. Stratigraphy of the carbonate-bearing sediments.

Olive-brown "Platelets" were collected with a bottom grab and a benthos tube at Sites 2000D, 2003G2, and 2003BSG-7 from the uppermost layer of the sediment $(8-10 \mathrm{~cm})$.

In core $2005 \mathrm{St} 3 \mathrm{GC} 1$, a grayish green carbonate platelet $3 \times 1.5 \mathrm{~cm}$ and approximately $0.4 \mathrm{~cm}$ thick was found at a depth of 102-105 cm (Fig. 2). The carbonate was surrounded by a zone of strongly reduced black sediment. The deposits are gas-rich diatom-bearing dark olive-gray sandy silt-pelite with a few sand lamina.

At Site 2004St3GC3, a platy carbonate nodule was contained in gas-rich silt-pelite from a depth of $130 \mathrm{~cm}$.

\section{Composition of Carbonates}

Dr. E.P. Solotchina (United Institute of Geology, Geophysics, and Mineralogy, Siberian Branch, Russian Academy of Sciences) was the first to determine that platelets (2003G2 and 2003BGC-7) from the Malen'kii mud volcano have a rhodochrosite-siderite composition.

Our X-ray diffraction analysis of carbonates from K-2 and Malen'kii mud volcanoes has demonstrated 

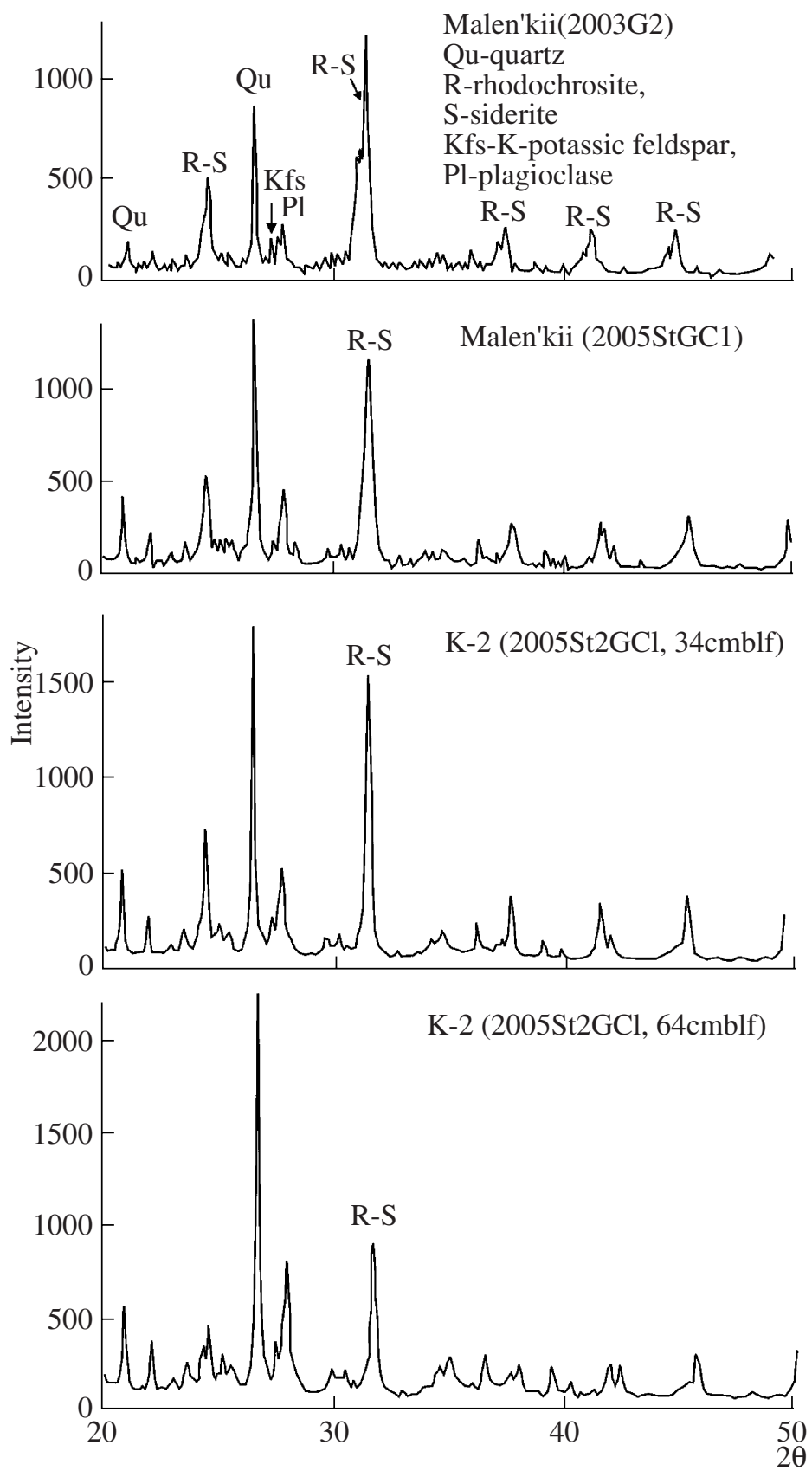

Fig. 3. Diffraction patterns of carbonate nodules.

their practically identical mineralogy. The position of the peak (104) varies between those of typical siderite $(2.80 \AA)$ and rhodochrosite $(2.85 \AA)$ (Fig. 1). However, the shift of the reflection (104) could also be accounted for by the incorporation of bivalent cations (such as $\mathrm{Ca}$ and $\mathrm{Mg}$ ) in the crystal lattice. The terrigenous admixture consists mainly of quartz, plagioclase, potassic feldspar, and clay minerals (Fig. 3). Trace amounts of magnesian calcite were identified by the reflection (104) approximately equal to $3.00 \AA$ (these values slightly vary from sample to sample).
Results of the ICP-AES analysis of the nodules show that they bear high concentrations of Fe [varying from $17.3 \%$ (K-2) to $38.2 \%$ (Malen'kii)] and low Mn contents [from $0.4 \%$ (K-2) to $3.2 \%$ (Malen'kii)] (Table 1). In addition to a carbonate phase, these cations can also be accommodated in the terrigenous admixture. Spot analyses of carbonate crystals on a scanning electron microscope confirm that $\mathrm{Fe}$ is the predominant element of the carbonates (77-90 mol \%). This element can be isomorphically substituted for $\mathrm{Ca}(7-20 \mathrm{~mol} \%)$ and, to a lesser degree, $\mathrm{Mn}(0-4 \mathrm{~mol} \%)$ and $\mathrm{Mg}(0-4 \mathrm{~mol} \%)$. 
Table 1. Chemical composition of authigenic carbonates from Lake Baikal

\begin{tabular}{|c|c|c|c|c|c|c|c|}
\hline \multirow{2}{*}{ Site } & \multirow{2}{*}{ Sampling depth, cm } & \multirow{2}{*}{$d_{(104)}, \AA$} & \multirow{2}{*}{$\begin{array}{l}\text { Siderite concentration } \\
\text { (wt \%) }\end{array}$} & \multicolumn{4}{|c|}{ Concentration (wt $\%$, ICP data) } \\
\hline & & & & $\mathrm{Ca}$ & $\mathrm{Mg}$ & $\mathrm{Fe}$ & $\mathrm{Mn}$ \\
\hline \multicolumn{8}{|c|}{ Malen'kii } \\
\hline $2003 \mathrm{G} 2$ & $8-10$ & $2.816 ; 2.843$ & 51 & 4.1 & 1.3 & 31.3 & 1.1 \\
\hline 2003BGC-7 & $8-10$ & 2.845 & 37 & n.a. & n.a. & n.a. & n.a. \\
\hline $2005 \mathrm{St} 3 \mathrm{GC} 1$ & $104-105$ & 2.823 & 71 & 2.1 & 1.0 & 28.2 & 1.5 \\
\hline 2000D & 10 & 2.842 & 60 & n.a. & n.a. & n.a. & n.a. \\
\hline 2004St3GC3, & 130 & & & & & & \\
\hline outer zone & & 2.839 & 63 & 5.3 & 1.4 & 30.4 & 0.8 \\
\hline inner zone & & 2.842 & 76 & 5.6 & 1.2 & 38.2 & 3.2 \\
\hline \multicolumn{8}{|c|}{$\mathrm{K}-2$} \\
\hline $2005 \mathrm{St} 2 \mathrm{GC} 1$ & 34 & 2.817 & 35 & 2.1 & 2.2 & 24.3 & 0.6 \\
\hline $2005 \mathrm{St} 2 \mathrm{GC} 1$ & 64 & 2.822 & 14 & 4.5 & 2.6 & 17.3 & 0.4 \\
\hline
\end{tabular}

Note: n.a. means not analyzed.

Table 2. Isotopic composition of carbonate nodules from Lake Baikal

\begin{tabular}{|c|c|c|c|c|c|}
\hline \multirow{3}{*}{ Site } & \multicolumn{2}{|c|}{ Measured } & \multirow{3}{*}{$10^{3} \ln \alpha_{\text {siderite-water }}{ }^{*}$} & \multicolumn{2}{|c|}{ Theoretical $^{* * *}$} \\
\hline & $\delta^{13} \mathrm{C}$ & $\delta^{18} \mathrm{O}$ & & \multirow{2}{*}{$\begin{array}{c}\delta^{18} \mathrm{O}_{\text {water }} \% \text { \%o } \\
\text { SMOW }^{* * *}\end{array}$} & \multirow{2}{*}{$T^{\circ} \mathrm{C}^{* * * * *}$} \\
\hline & \multicolumn{2}{|c|}{ PDB } & & & \\
\hline \multicolumn{6}{|c|}{ Malen'kii } \\
\hline $2003 \mathrm{G} 2$ & 3.3 & -11.3 & 34.39 & -15.7 & 5.6 \\
\hline 2003BGC7 & 6.1 & -11.4 & 34.29 & -15.8 & 6.0 \\
\hline 2005St3GC1 & 4.8 & -10.6 & 35.10 & -15.1 & 3.0 \\
\hline 2000D & 6.4 & -10.9 & 34.80 & -15.3 & 4.1 \\
\hline 2004St3GC3 (outer zone) & 6.8 & -10.8 & 34.90 & -15.2 & 3.7 \\
\hline 2004St3GC3 (inner zone) & 5.9 & -11.6 & 34.09 & -16.0 & 6.7 \\
\hline \multicolumn{6}{|l|}{  } \\
\hline $2005 \mathrm{St} 2 \mathrm{GC} 1-34 \mathrm{~cm}$ & 21.9 & -12.7 & 33.08 & -17.1 & 10.6 \\
\hline $2005 \mathrm{St} 2 \mathrm{GC} 1-64 \mathrm{~cm}$ & 17.7 & -13.9 & 31.86 & -18.3 & 15.6 \\
\hline \multicolumn{6}{|c|}{$\begin{array}{l}\text { Notes: } \quad * \delta^{18} \mathrm{O} \text { fractionation between siderite and water, where } \alpha=\left(\delta^{18} \mathrm{O}_{\text {siderite }} \mathrm{PDB}+1000\right) /\left(\delta^{18} \mathrm{O}_{\text {water }} \mathrm{PDB}+1000\right) \text {, and } \delta^{18} \mathrm{O} \text { are } \\
\text { measured values; } \\
* * \text { theoretical values calculated by the formula } 10^{3} \ln \alpha_{\text {siderite-water }}=2.89 \times 10^{6} \times T^{-2}-2.81[4] ; \\
* * * \text { theoretical value for pore water form which siderite could crystallize in equilibrium at } 3.5^{\circ} \mathrm{C} ; \\
* * * * \text { theoretical crystallization temperature of siderite at measured } \delta^{18} \mathrm{O} \text { of the pore water }(-15.2 \% \text { SMOW for Malen'kii and }- \\
\text { 15.3\%o SMOW for K-2). }\end{array}$} \\
\hline
\end{tabular}

Hence, all of our carbonate nodules from both mud volcanoes are made up of siderite.

Mass spectrometric measurements reveal insignificant enrichment of the carbonate in the ${ }^{13} \mathrm{C}$ isotope and their depletion in the ${ }^{18} \mathrm{O}$ isotope (Table 2). The platy nodules from Malen'kii volcano show $\delta^{13} \mathrm{C}$ from +3.3 to $+6.8 \%$ and $\delta^{18} \mathrm{O}$ from -10.6 to $-11.6 \%$, and the soft carbonate segregations from the K-2 mud volcano have $\delta^{13} \mathrm{C}$ from +17.7 to $+21.9 \%$ and $\delta^{18} \mathrm{O}$ from -12.7 to $-13.9 \%$.

GEOCHEMISTRY INTERNATIONAL Vol. 46 No. $10 \quad 2008$

\section{Composition of Gases}

In terms of its molecular composition, GH from the Malen'kii mud volcano consists of methane ( 99\%). In addition to methane (85.1-98.5\%), GH from the K-2 volcano also contains ethane (from 1.5 to $14.9 \%$ ) and minor propane (from 0.006 to $0.14 \%$ ) [23]. The molecular composition of gas extracted from the sediments by the head-space technique is generally analogous to the composition of the hydrates, except for the ethane concentration in gas from $\mathrm{K}-2$, which does not exceed $3 \%$ [24]. 
The isotopic composition of methane contained in the $\mathrm{GH}$ and dissolved in the pore water varies as follows: $\delta^{13} \mathrm{C}$ from -61.0 to $-66.0 \%, \delta \mathrm{D}$ from -294 to $-314 \%$ o for the Malen'kii mud volcano, and $\delta^{13} \mathrm{C}$ from -55.0 to $-58.3 \%$ and $\delta \mathrm{D}$ from -295 to $-305 \%$ o for the $\mathrm{K}-2$ mud volcano $[23,25]$. This isotopic composition testifies that this methane was produced via the bacterial destruction of acetate [26].

The isotopic composition $\left(\delta^{13} \mathrm{C}\right)$ of $\mathrm{C}_{2} \mathrm{H}_{6}$ in hydrates from K-2 varies from -24.9 to $-26.6 \%$.

\section{Pore Water Chemistry}

$\mathrm{Mn}$ concentrations vary from 0.4643 to $1.6207 \mu \mathrm{mol} / \mathrm{l}$, and those of Fe vary from 0.4211 to $17.7145 \mu \mathrm{mol} / 1$ (measured only in core 2005St2GC1). These values are much higher than in the bottom water sampled at a depth of $50 \mathrm{~cm}$ from the lake floor: $0.0004136 \mu \mathrm{mol} / 1 \mathrm{Mn}$ and $0.04082 \mu \mathrm{mol} / \mathrm{l} \mathrm{Fe}$.

The distributions of the $\mathrm{HCO}_{3}^{-}$and $\mathrm{SO}_{4}^{2-}$ anions in the vertical sections generally show opposite trends: the bicarbonate content increases after the reduction of sulfates. This scheme is most likely complicated because of sporadic inflows of discrete portions of fluid saturated with sulfates and bicarbonate [27] and/or due to the stirring of the mud-volcano breccia. At Sites 2005St3GC1 and 2005St2GC1, sulfate is greatly reduced at depths greater than $30 \mathrm{~cm}$ (Fig. 4).

We calculated the saturation coefficients of the pore waters in core 2005 St2GC1 with respect to carbonates (aragonite, dolomite, calcite, rhodochrosite, and siderite) by the formula

$$
\Omega=\log \frac{\left[\mathrm{Me}^{2+}\right] \cdot\left[\mathrm{CO}_{3}^{2-}\right]}{K s p},
$$

where $\left[\mathrm{Me}^{2+}\right]$ and $\left[\mathrm{CO}_{3}^{2-}\right]$ are the activities of the ions, which are functions of their concentrations in the pore water and the ionic strength of the solution at the in-situ measured temperature $\left(4^{\circ} \mathrm{C}\right)$; $\mathrm{Me}^{2+}$ denotes the cations contained in the crystal structures of the carbonates; and $K s p$ is the solubility product of the carbonates. The crystallization of carbonates is possible at $\Omega>0$. The calculations presented above were carried out by the PHREEQC computer program for Windows [28].

Figure 5 shows that, depending on the activities of ions, siderite can crystallize at certain levels in core $2005 \mathrm{St} 2 \mathrm{GC} 1$ at $\mathrm{pH}>7.6$. Our simulation results also imply that no other carbonates can be produced in this core at $\mathrm{pH}$ from 7 to 8 .

\section{DISCUSSION}

\section{Diagenesis of the Bottom Sediments}

As has been established previously, the concentration of the $\mathrm{Ca}^{2+}$ ion in the pore waters of bottom sediments in Lake Baikal is insufficient for authigenic cal- cite to crystallize, whereas foreign $\mathrm{Ca}$ carbonates that are brought to the lake rapidly dissolve [18]. At the same time, the Fe and Mn concentrations in the sediments are sufficient for the development of layers enriched in Fe and Mn oxides, as well as $\mathrm{Fe}-\mathrm{Mn}$ and $\mathrm{Mn}-\mathrm{Fe}$ crusts and nodules [29, 30].

Authigenic siderite and rhodochrosite are commonly formed in lacustrine deposits; this process is controlled by diagenesis [31, 32]. The geochemical behavior of $\mathrm{Fe}$ and $\mathrm{Mn}$ is known to be controlled by the position of the boundary between the aerobic and anaerobic zones. $\mathrm{Fe}^{3+}$ and $\mathrm{Mn}^{4+}$ oxides are characterized by low mobility, and they readily precipitate and form ferromanganese crusts and nodules in upper layers of sediments [29]. Reduced under anaerobic conditions, $\mathrm{Fe}^{2+}$ and $\mathrm{Mn}^{2+}$ easily migrate, but these cations can form rhodochrosite and siderite if the pore waters are oversaturated in these cations and contain sufficient concentrations of hydrocarbonate [31].

In cores 2005St3GC1 and 2005St2GC1, aerobic environments give way to anaerobic ones at a depth of approximately $30 \mathrm{~cm}$ (Fig. 4). Soft carbonates from the K-2 mud volcano occur immediately beneath this boundary (34 and $64 \mathrm{~cm})$. Solid carbonate platelets in cores 2004St3GC3 and 2005St3GC1 from the Malen'kii mud volcano occur at much more significant depths (130 and 102-105 cm, respectively), whereas the carbonate platelets lifted with a core grab from Sites 2000D, 2003G2, and 2003BGC7 occurred at levels of 8-10 cm (and their oxidized layer was a few millimeters thick).

All siderite samples found in surface sediments of Lake Baikal were spatially restricted only to the discharge zone of fluids. Hence, only these domains contain enough $\mathrm{HCO}_{3}^{-}$to form carbonates; otherwise authigenic carbonates should have occurred everywhere, considering the fact that Baikal waters are saturated with $\mathrm{Fe}$ and $\mathrm{Mn}$. Since the deposits of the Malen'kii and K-2 mud volcanoes are rich in methane and contain $\mathrm{GH}$, we concluded that this bicarbonate is genetically related to hydrocarbon discharge. At the same time, carbonates and hydrocarbons (methane and ethane) are characterized by a principally different carbon isotopic composition, which likely makes relations between them not as self-evident.

\section{Carbon Isotopic Composition}

Authigenic carbonates formed at fluid discharge sites in the surface layers of bottom sediments were previously found only in marine environments. Their genesis is related mostly to the anaerobic oxidation of methane, therefore the nodules have negative $\delta^{13} \mathrm{C}[12,14]$.

Our samples of newly formed carbonates are characterized by very high concentrations of ${ }^{13} \mathrm{C}$ (Table 2 ). We are aware of only a few finds of authigenic carbonates at areas with $\mathrm{GH}$ having positive $\delta^{13} \mathrm{C}$ values, and practically all of them occurred at significantly far 


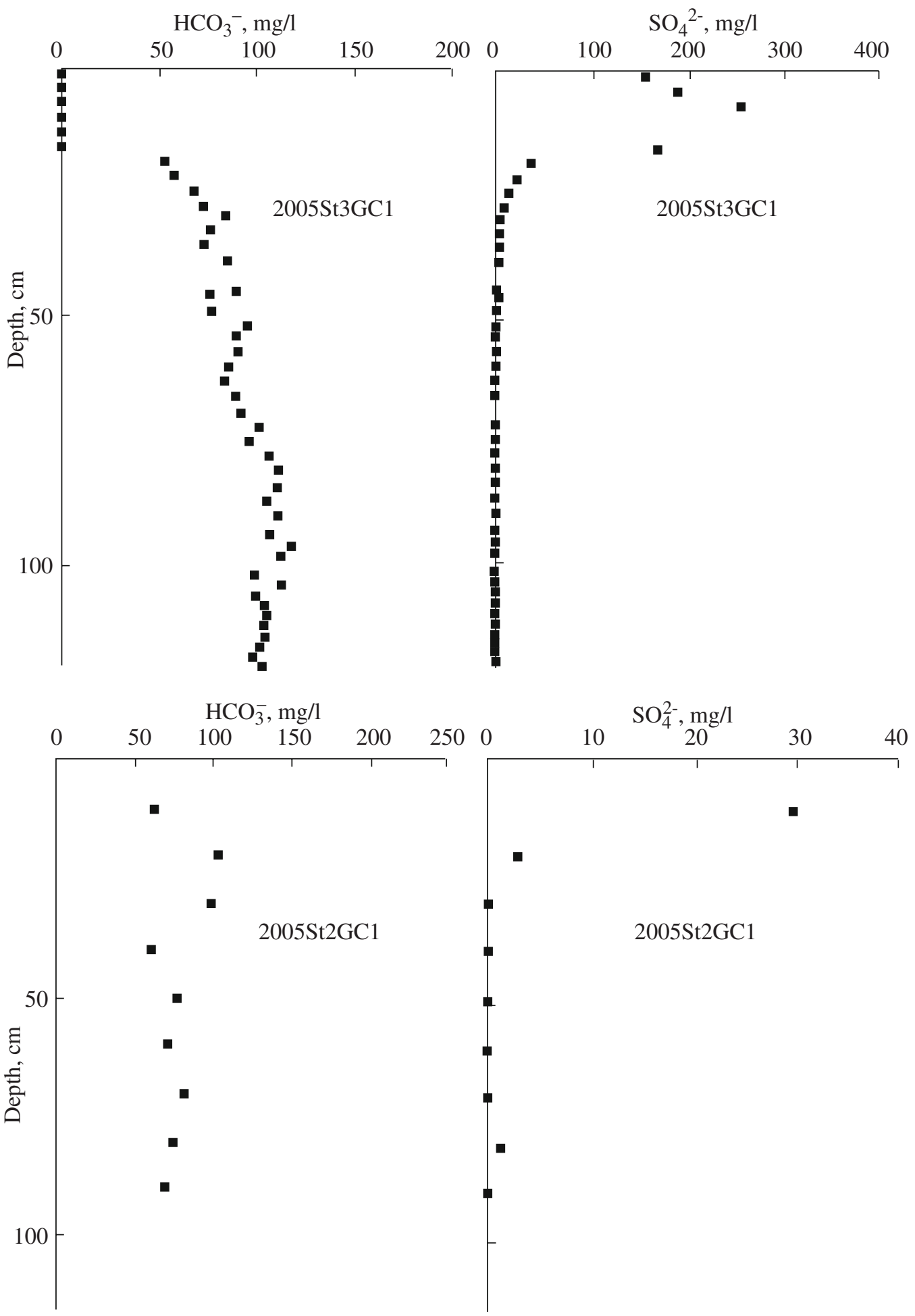

Fig. 4. Distribution of sulfates and carbonates in the pore waters.

below the surface of the seafloor (at depths from tens to a few hundred meters). Examples are siderite from the Blake Outer Ridge $\left(\delta^{13} \mathrm{C}\right.$ from +8.6 to $+12.5 \%$ o PDB [33]), the cement of carbonate nodules from deposits in the Cascadia continental margin $\left(\delta^{13} \mathrm{C}\right.$ up to $+24.32 \%$ o
$[34,35])$, and the carbonate cement of authigenic aggregates from the Peru Trench $\left(\delta^{13} \mathrm{C}\right.$ up $+19.0 \%$ o [36]). Such an isotopically heavy composition of carbon is explained by the synthesis of $\mathrm{CO}_{2}$ when $\mathrm{CH}_{4}$ is generated via the destruction of organic matter. In con- 


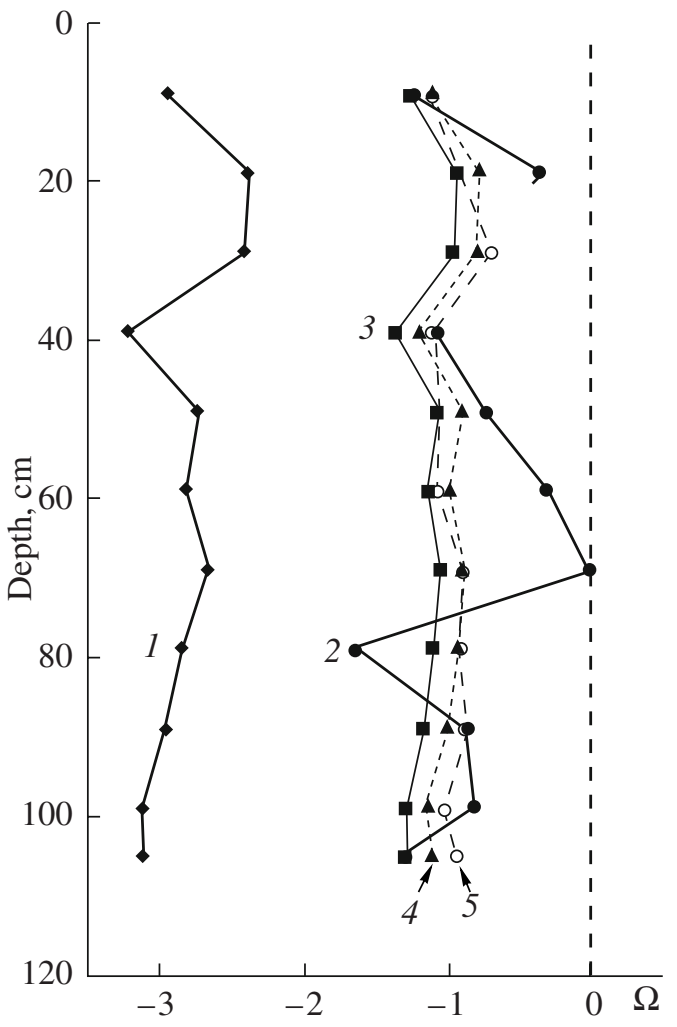

Fig. 5. Saturation of pore water in core $2005 \mathrm{St} 2 \mathrm{GC} 1$ with respect to carbonates at $\mathrm{pH} 7.6$ and a temperature of $4{ }^{\circ} \mathrm{C}$. Numerals: (1) dolomite, (2) siderite, (3) aragonite, (4) calcite, (5) rhodochrosite

trast to these examples, our siderite samples were taken from fresh-water sediments near the bottom surface.

Obviously, the mechanisms of methane oxidation cannot be invoked in this instance to account for the genesis of authigenic carbonates in Lake Baikal. Such a significant ${ }^{13} \mathrm{C}$ concentration in these carbonates can be produced only if methane was generated by the bacterial destruction of organic matter [26, 37]. It is known that much organic matter contained in the sediments is brought to the lake by the Selenga River and by the high sedimentation flux of phytoplankton $(90 \%$ of which is diatoms) [38]. The highest concentrations of organic matter (1.5-2.5\%) are contained in the central zone of the Southern and Central basins in Lake Baikal [39].

There are only a limited number of compounds that can be utilized by bacteria to synthesize methane. The most widely spread reactions are the destruction of acetate and reduction of carbon dioxide [40]. It was demonstrated above that the isotopic composition of methane of the volcanoes indicates that it was generated by the destruction of acetate. The acetoclastic genesis of methane, the predominant mechanism of methane synthesis in freshwater reduced environments, is described by the reaction [26]

$$
\mathrm{CH}_{3} \mathrm{COOH} \longrightarrow \mathrm{CH}_{4}+\mathrm{CO}_{2} \text {. }
$$

As a consequence of this process, the light and heavy $\mathrm{C}$ isotopes are preferably concentrated in $\mathrm{CH}_{4}$ and $\mathrm{CO}_{2}$, respectively. Inasmuch as $\mathrm{pH}$ varies in sediments in Lake Baikal from 7 to 8, dissolved inorganic carbon occurs predominantly in the form of bicarbonate

$$
\mathrm{CO}_{2}+\mathrm{H}_{2} \mathrm{O} \rightleftarrows \mathrm{HCO}_{3}^{-}+\mathrm{H}^{+} \text {. }
$$

As was demonstrated above, pore waters in the structures in question may be oversaturated with respect to siderite, which should then precipitate according to the reaction

$$
\mathrm{Fe}^{2+}+2 \mathrm{HCO}_{3}^{-} \rightleftarrows \mathrm{FeCO}_{3}+\mathrm{CO}_{2}+\mathrm{H}_{2} \mathrm{O} \text {. }
$$

It is known that the difference between the $\mathrm{C}$ isotopic composition of $\mathrm{CH}_{4}$ and $\mathrm{CO}_{2}$ in freshwater reduced environments with the predominance of acetoclastic $\mathrm{CH}_{4}$ genesis amounts to 40-55\% [26]. Carbon isotopic fractionation between $\mathrm{CO}_{2}$ and crystallizing siderite may be as high as approximately $19 \%$ at $4^{\circ} \mathrm{C}$, and the solid phase is thereby enriched in the heavy isotope [41]. Thus, the difference in the carbon isotopic composition of methane and siderite from the mud volcanoes in question should be 59-74\%o, which is consistent with the actual measured values.

Acetate was not determined in samples from the mud volcanoes in Baikal, but it is known that its concentration in surface sediments from other parts of the lake is $0.1-2.36 \mathrm{mg} \mathrm{C/l} \mathrm{[42].} \mathrm{These} \mathrm{values} \mathrm{are} \mathrm{insuffi-}$ cient to produce the bicarbonate concentrations required for siderite to crystallize from the solution. Hence, the processes described by reactions (2) and (3) most probably occur at depths of a few hundred meters, after which the newly generated hydrocarbon gases and bicarbonate ascent together with the mud-volcano fluid. This idea finds support in the results of earlier studies [43] which suggested that acetate is most actively generated at temperatures of $10-60^{\circ} \mathrm{C}$. The example of the Blake Ridge, where hydrates were found, demonstrates that acetate concentrations significantly increase with depth [43].

The carbon isotopic composition of siderite from the $\mathrm{K}-2$ mud volcano is $>10 \%$ o heavier than that of Malen'kii volcano (Table 2). This can be explained by differences in the isotopic composition of the source material and/or by other factors and processes, such as the complication of acetoclastic methane genesis by methane oxidation near the surface or the activation of methane synthesis due to the reduction of carbon dioxide.

\section{OXYGEN ISOTOPIC COMPOSITION}

The oxygen isotopic composition of carbonates is controlled by (1) the $\delta^{18} \mathrm{O}$ of the water from which they crystallize and (2) the temperature of the crystallization process. Since we know all of these parameters (the temperature of the sediment is $3.5^{\circ} \mathrm{C}$, and the average $\delta^{18} \mathrm{O}$ values of the pore water is $-15.3 \%$ SMOW for 


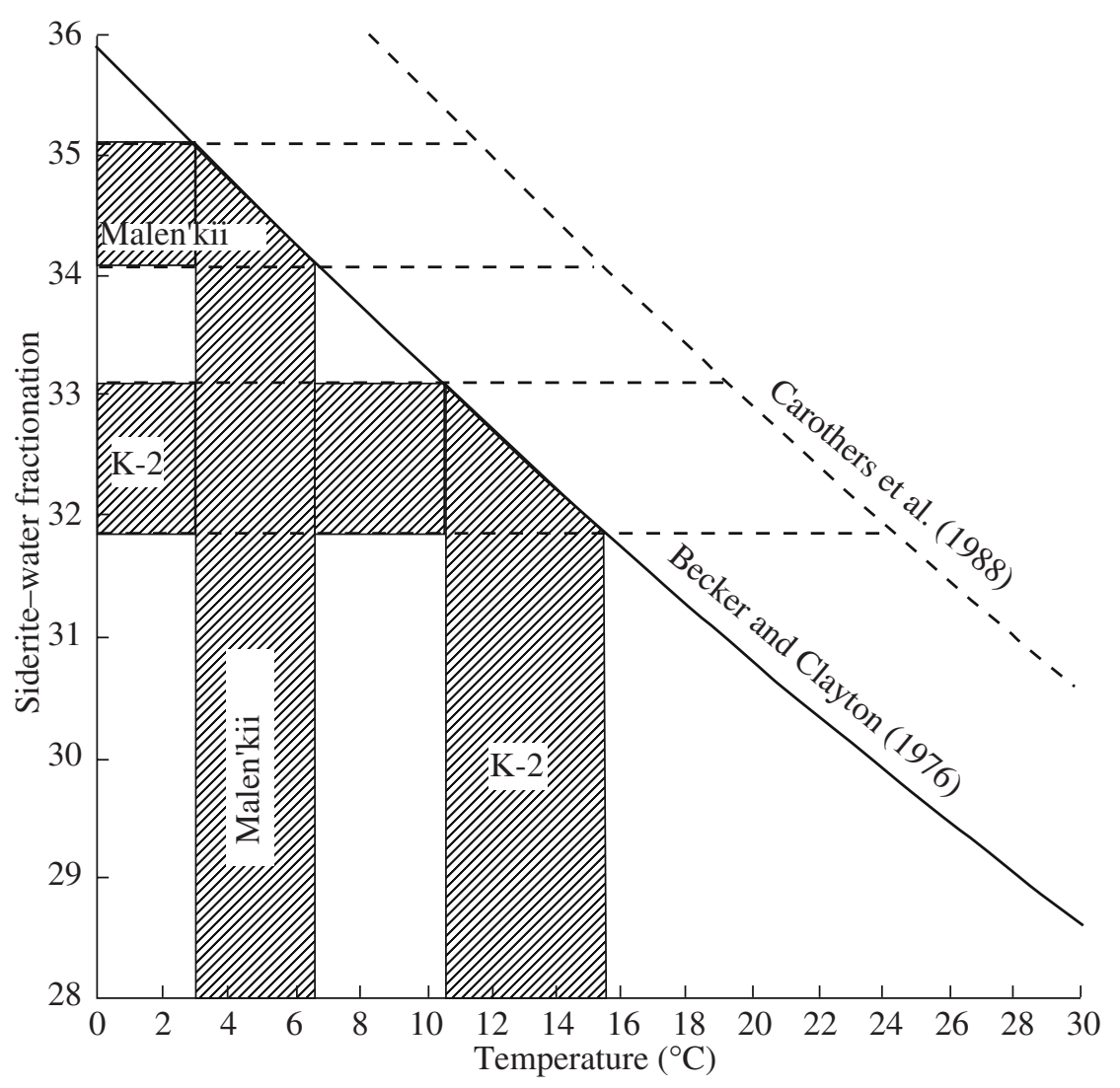

Fig. 6. Theoretical crystallization temperature of siderite at the Malen'kii and K-2 mud volcanoes (shaded fields) obtained using

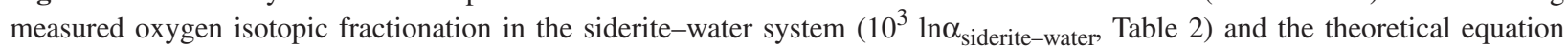
$10^{3} \ln \alpha_{\text {siderite-water }}=2.89 \times 10^{6} T^{-2}-2.81$ [44] (solid line). The solid dashed line was drawn according to the experimental equation $10^{3} \ln \alpha=3.13 \times 10^{6} T^{-2}-3.50[45]$.

K-2 and -15.2\%o SMOW for Malen'kii), we can determine whether the carbonates were formed in equilibrium. Many equations were developed to calculate the equilibrium parameters of siderite crystallization [44-47], but none of them is suitable for calculating the crystallization of "impure" siderite in the nodules. The experimental equations $[45,46]$ were derived at relatively high temperatures $\left(>33^{\circ} \mathrm{C}\right)$, therefore their application to low temperatures near the bottom $\left(3.5^{\circ} \mathrm{C}\right)$ may lead to errors. In our calculations we borrowed the theoretical equation from [44]. It should be mentioned that a $\mathrm{Ca}$ isomorphic admixture in siderite decreases the equilibrium crystallization temperature, which cannot be taken into account in equations for "pure" carbonates. If Ca substitutes $10 \% \mathrm{Fe}$ in siderite, the crystallization temperature of the latter decreases by approximately $1{ }^{\circ} \mathrm{C}$.

According to our results, the calculated and measured values are satisfactorily consistent only for carbonate platelets from the Malen'kii mud volcano (Table 2, Fig. 6). The theoretical temperature of siderite crystallization at the K-2 mud volcano is much higher than the temperature measured in situ (Table 2, Fig. 6). These data are shown in Fig. 6, which illustrates the depen- dence between the measured values of oxygen fractionation in the siderite-water system $\left(10^{3} \ln \alpha_{\text {siderite-water }}\right.$ Table 2) and the corresponding calculated theoretical temperatures of siderite crystallization. For comparison, Fig. 6 presents a dashed line based on the experimentally derived equation [45]. It is clear that the equilibrium temperatures of siderite crystallization determined using this line are much higher and do not correspond to those measured at both mud volcanoes.

At the same time, assuming that the carbonates crystallized at the ambient temperature of $+3.5^{\circ} \mathrm{C}$, we arrive at the conclusion that the oxygen isotopic composition of the pore water $\left(\delta^{18} \mathrm{O}\right)$ should vary from -15.1 to $-16 \%$ SMOW for the Malen'kii mud volcano and from -17.1 to $-18.3 \%$ o SMOW for the K-2 mud volcano (Table 2). These values are generally consistent with the isotopic composition of pore water from the Malen'kii mud volcano but are much "lighter" than that at K-2. Hence, the soft siderite nodules at K-2 either were formed from pore water of lighter oxygen isotopic composition than that of the modern water or crystallized at higher temperatures (Table 2).

However, siderite at K-2 could not grow at temperatures higher than $13.4^{\circ} \mathrm{C}$, because the nearby $\mathrm{GH}$ would 
have decomposed. This also follows from the calculated equilibrium temperatures of $\mathrm{GH}$ stability, which are $13.4^{\circ} \mathrm{C}$ for methane hydrates with crystalline structure I and $14.4^{\circ} \mathrm{C}$ for hydrates with crystalline structure II. The calculations were conducted by method [48] using data on the composition of GH from [23] and the hydrostatic pressure corresponding to a water depth of $980 \mathrm{~m}$. This implies that siderite at K-2 most likely crystallized from water depleted in ${ }^{18} \mathrm{O}$. It is known that the residual water of light oxygen isotopic composition is formed during the generation of $\mathrm{GH}$, because the latter generally concentrate ${ }^{18} \mathrm{O}$. The conclusion that the soft siderite nodules crystallized from residual water is reached because of their occurrence near GH. Hard siderite platelets of Malen'kii mud volcano were, according to calculations, formed from water analogous to the modern pore water.

\section{CONCLUSIONS}

Siderite carbonates crystallize in surface sediment near discharge sites of fluids in Lake Baikal in the form of either soft nodules (at the K-2 mud volcano) or dense semirounded platelets (at the Malen'kii mud volcano) and are significantly enriched in the heavy oxygen isotope.

The definite spatial restriction of the surface carbonates to gas-hydrate mud volcanoes testifies to a genetic relation between carbon in the methane and siderite. The most plausible explanation of the principal difference between their isotopic compositions is the mechanism of methane generation from carbon dioxide via the bacterial destruction of organic matter (acetate), a process widespread in fresh-water environments.

Theoretical calculations of the equilibrium temperatures of carbonate crystallization indicate that the soft carbonate nodules of the K-2 mud volcano (Kukui Canyon, Central Basin) were most probably produced with the participation of residual water released after $\mathrm{GH}$ synthesis. The dense carbonate platelets of the Malen'kii mud volcano (Southern Basin) were formed from water of isotopic composition analogous to that of the modern pore water.

\section{ACKNOWLEDGMENTS}

This study was financially supported by the Japan Society for the Promotion of Science KAKENHI 18206099 and Integration Project 58 of the Siberian Branch of the Russian Academy of Sciences.

\section{REFERENCES}

1. D. R. Khatchinson, A. Yu. Gol'mshtok, L. P. Zonenshain, et al., "Features of Structure of the Sedimentary Sequence of Lake Baikal Based on the Results of a Multifrequency Seismic Survey (1989)," Geol. Geofiz. 34 (10-11), 25-36 (1993).
2. A. G. Efremova, M. V. Andreeva, T. V. Levshenko, et al., "On Gases in the Baikal Sediments," Gazov. Promyshlen. Ser. Geol. Razvedka Gaz. Kondens. Mestorozhd., No. 2, 15-27 (1980).

3. D. R. Hutchinson, M. W. Lee, W. F. Agena, et al., "Processing of Lake Baikal Marine Multichannel Seismic Reflection Data," USGS Open-File Rept., No. 93-201, 1-24 (1992).

4. M. I. Kuz'min, G. V. Kalmychkov, V. A. Geletii, et al., "The First Find of Gas-Hydrates in the Sedimentary Rocks of Lake Baikal," Dokl. Akad. Nauk 362, 541-543 (1998) [Dokl. Earth Sci. 362, 1029-1031 (1998)].

5. M. Vanneste, M. De Batist, A. Golmshtok, et al., "Multifrequency Seismic Study of Gas Hydrate-Bearing Sediments in Lake Baikal, Siberia," Mar. Geol. 172, 1-21 (2001).

6. P. van Rensbergen, M. De Batist, J. Klerkx, et al., "Sublacustrine Mud Volcanoes and Methane Seeps Caused by Dissociation of Gas Hydrates in Lake Baikal," Geology 30, 631-634 (2002).

7. O. M. Khlystov, J. Klerkx, and M. de Batist, "Bottom Sediments Containing Subsurface Gas Hydrates in Lake Baikal," in Proceedings of 3rd Vereshchagin Baikal Conference, Irkutsk, Russia, 2000 (Irkutsk, 2000), p. 258 [in Russian].

8. J. Klerkx, T. I. Zemskaya, T. V. Matveeva, et al., "Methane Hydrates in Deep Bottom Sediments of Lake Baikal," Dokl. Akad. Nauk 393, 822-826 (2003) [Dokl. Earth Sci. 393, 1342-1346 (2003)].

9. T. V. Matveeva, L. L. Mazurenko, V. A. Soloviev, et al., "Gas Hydrate Accumulation in the Subsurface Sediments of Lake Baikal (Eastern Siberia)," Geo-Mar. Lett. 23, 289-299 (2003).

10. O. M. Khlystov, O. V. Shubenkova, S. M. Chernitsyna, et al., "Geological and Biogeochemical Study of Baikal Sediments at a Methane Discharge Site," in Proceedings of Lavrent'ev Conference of Young Scientists, Novosibirsk, Russia, 2003 (Novosibirsk, 2003), pp. 209-214 [in Russian].

11. O. M. Khlystov, "New Finds of Gas Hydrates in the Bottom Sediments of Lake Baikal," Geol. Geofiz. 47, 979981 (2006).

12. A. Yu. Lein, "Authigenic Carbonate Formation in the Ocean," Lithol. Mineral Resour. 39, 1-30 (2004).

13. J. B. Martin, M. Kastner, P. Henry, et al., "Chemical and Isotopic Evidence for Sources of Fluids in a Mud Volcano Field Seaward of the Barbados Accretionary Wedge,” J. Geophys. Res. 101, 20325-20345 (1996).

14. U. von Rad, H. Rosch, H. Berner, et al., "Authigenic Carbonates Derived from Oxidized Methane Vented from the Makran Accretionary Prism Off Pakistan," Mar. Geol. 136, 55-77 (1996).

15. L. M. Knyazeva, "Vivianite in Bottom Mud from Lake Baikal,” Dokl. Akad. Nauk SSSR 97, 519-522 (1964).

16. K. K. Falkner, C. I. Measures, S. E. Herbelin, and J. M. Edmond, "The Major and Minor Element Geochemistry of Lake Baikal,” Limnol. Oceanogr. 36, 413-423 (1991).

17. E. Callender and L. Granina, "Transition Metal Geochemistry of Sedimentary Pore Fluids Associated with Hydrothermal Activity in Lake Baikal, Russia," in Proceedings of 7th Int. Conference on Water-Rock Inter- 
action, WRI-7 Park City Utah, United States, 1992, (Balkema, Rotterdam, 1992), pp. 621-626.

18. I. B. Mizandrontsev, "On the Geochemistry of Ground Solutions," in Dynamics of the Baikal Basin (Nauka. Sib. Otd., Novosibirsk, 1975), pp. 203-231 [in Russian].

19. The Baikal Drilling Project Group, "Late Cenozoic Paleoclimatic Record in the Lake Baikal Sediments Based on the Results of a 600-m Deep Drilling Core," Geol. Geofiz. 41, 3-32 (2000).

20. T. Sapota, A. Aldahan, and I. S. Al-Aasm, "Sedimentary Facies and Climate Control on Formation of Vivianite and Siderite Microconcretions in Sediments of Lake Baikal, Siberia,” J. Paleolimnol. 36, 245-257 (2006).

21. S. Das Sharma, D. J. Patil, and K. Gopalan, "Temperature Dependence of Isotopic Fractionation of $\mathrm{CO}_{2}$ from Magnesite-Phosphoric Acid Reaction," Geochim. Cosmochim. Acta 66, 589-593 (2002).

22. J. Rosenbaum and S. M. F. Sheppard, "An Isotopic Study of Siderites, Dolomites and Ankerites at High Temperatures," Geochim. Cosmochim. Acta 50, 1147-1150 (1986).

23. M. Kida, O. Khlystov, T. Zemskaya, et al., "Coexistence of Structure I and II Gas Hydrates in Lake Baikal Suggesting Gas Sources from Microbial and Thermogenic Origin," Geophys. Res. Lett. 33, L24603 (2006).

24. G. V. Kalmychkov, A. V. Egorov, M. I. Kuz'min, and O. M. Khlystov, "Genetic Types of Methane from Lake Baikal,” Dokl. Earth Sci. 411, 1462-1465 (2006).

25. M. Kida, Crystallographic Studies on Synthetic and Natural Gas Hydrates by ${ }^{13}$ C NMR Technique Ph.D. Thesis (Kitami Institute of Technology, 2007) [in Japanese].

26. M. J. Whiticar, "Carbon and Hydrogen Isotope Systematics of Bacterial Formation and Oxidation of Methane," Chem. Geol. 161, 291-314 (1999).

27. L. Z. Granina, E. Callender, I. S. Lomonosov, et al., "Compositional Anomaly of Pore Waters in Baikal Bottom Sediments," Geol. Geofiz. 42, 362-372 (2001).

28. D. L. Parkhurst and C. A. J. Appelo, "User's Guide to PHREEQC (Version 2) - A computer Program for Speciation, Batch-Reaction, One-Dimensional Transport, and Inverse Geochemical Calculations," Water Res. Investigations Rept. No. 99-4259 (Denver, Colorado, 1999).

29. R. G. Deike, L. Granina, E. Callender, and J. J. McGee, "Formation of Ferric Iron Crusts in Quaternary Sediments of Lake Baikal, Russia, and Implication for Paleoclimate," Mar. Geol. 139, 21-46 (1997).

30. L. Granina, B. Muller, and B. Wehrli, "Origin and Dynamic of $\mathrm{Fe}$ and Mn Sedimentary Layers in Lake Baikal," Chem. Geol. 205, 55-72 (2004).

31. W. Davison, "Iron and Manganese in Lakes," Earth-Science Rev. 34, 119-163 (1993).

32. J. A. Robbins and E. Callender, "Diagenesis of Manganese in Lake Michigan Sediments," Am. J. Sci. 275, 512-533 (1975).

GEOCHEMISTRY INTERNATIONAL Vol. 46 No. 10
33. R. Matsumoto, "Isotopically Heavy Oxygen-Containing Siderite Derived from the Decomposition of Methane Hydrate," Geology 17, 707-710 (1989).

34. A. Kopf, J. C. Sample, P. Bauer, et al., "Diagenetic Carbonates from Cascadia Margin: Textures, Chemical Composition, and Oxygen and Carbon Stable Isotope Signatures," Proc. ODP, Sci. Res. 146 (1), 117-136 (1995).

35. J. C. Sample and A. Kopf, "Isotope Geochemistry of Syntectonic Carbonate Cements and Veins from the Oregon Margin: Implication for the Hydrogeologic Evolution of the Accretionary Wedge," Proc. ODP, Sci. Res. 146 (1), 137-147 (1995).

36. T. M. Thornburg and E. Suess, "Carbonate Cementation of Granular and Fracture Porosity: Implications for the Cenozoic Hydrologic Development of the Peru Continental Margin," Proc. ODP, Sci. Res. 112, 95-109 (1990).

37. H. Irwin, C. Curtis, and M. Coleman, "Isotopic Evidence for Source of Diagenetic Carbonates Formed During Burial of Organic-Rich Sediments," Nature 269, 209213 (1977).

38. L. A. Vykhristyuk, Organic Matters of the Baikal Bottom Sediments (Nauka, Novosibirsk, 1980) [in Russian].

39. L. A. Vykhristyuk, "On Supply and Distribution of Major Chemical Elements in the Baikal Bottom Sediments," Litol. Polezn. Iskop., No. 1, 54-65 (1977).

40. R. Conrad, "Quantification of Methanogenic Pathway Using Stable Carbon Isotopic Signatures: A Review and Proposal," Organic Geochem. 36, 739-752 (2005).

41. S. I. Golyshev, N. L. Padalko, and S. A. Pechenkin, "Fractionation of Stable Oxygen and Carbon Isotopes in Carbonate Systems," Geochem. Int. 18, 85-99 (1981).

42. B. B. Namsaraev and T. I. Zemskaya, Microbiological Processes of the Carbon Cycle in the Bottom Sediments of Lake Baikal (Geo, Novosibirsk, 2000) [in Russian].

43. P. Wellsbury, K. Goodman, T. Barth, et al., "Deep Marine Biosphere Fuelled by Increasing Organic Matter Availability during Burial and Heating," Nature 388, 573-576 (1997).

44. R. H. Becker and R. N. Clayton, "Oxygen Isotope Study of a Precambrian Banded Iron-Formation, Hamersley Range, Western Australia," Geochim Cosmochim. Acta 40, 1153-1165 (1976).

45. W. W. Carothers, L. H. Adami, and R. J. Rosenbauer, "Experimental Oxygen Isotope Fractionation between Siderite-Water and Phosphoric Acid Liberated $\mathrm{CO}_{2}$-Siderite," Geochim. Cosmochim. Acta 52, 24452450 (1988).

46. C. L. Zhang, J. Horita, D. R. Cole, et al., "TemperatureDependent Oxygen and Carbon Isotope Fractionations of Biogenic Siderite," Geochim. Cosmochim. Acta 65, 2257-2271 (2001).

47. Y-F. Zheng, "Oxygen Isotope Fractionation in Carbonate and Sulfate Minerals," Geochem. J. 33, 109-126 (1999).

48. E. D. Sloan, Jr. Clathrate Hydrates of Natural Gases, (Marcel Dekker, New York, 1998) 
Reproduced with permission of the copyright owner. Further reproduction prohibited without permission. 